\title{
MAGNETO-THERMO-MECHANICAL BUCKLING ANALYSIS OF MINDLIN PLATE REINFORCED WITH FG-CARBON NANOTUBES
}

\author{
R. KOLAHCHI ${ }^{1}$, M. ESMAILPOUR ${ }^{2}$, M. SAFARI ${ }^{1}$
}

\begin{abstract}
A buckling analysis of temperature-dependent embedded plates reinforced by single-walled carbon nanotubes (SWCNTs) subjected to a magnetic field is investigated. The SWCNTs are distributed as uniform (UD) and three types of functionally graded nanotubes (FG), in which the material properties of the nano-composite plate are estimated based on the mixture rule. The surrounding temperature-dependent elastic medium is simulated as Pasternak foundation. Based on the orthotropic Mindlin plate theory, the governing equations are derived using Hamilton's principle. The buckling load of the structure is calculated based on an exact solution by the Navier method. The influences of elastic medium, magnetic field, temperature and distribution type, and volume fractions of SWCNT are shown on the buckling of the plate. Results indicate that CNT distribution close to the top and bottom are more efficient than that distributed near the mid-plane for increasing the stiffness of the plates.
\end{abstract}

Keywords: Buckling; Magnetic field; FG-SWCNTs; Temperature-dependent; Mindlin plate

\section{INTRODUCTION}

Most investigations of carbon nanotube-reinforced composites (CNTRCs) have focused on material properties and researchers have discovered that the mechanical, electrical and thermal properties of polymer composites can be considerably improved by adding small amounts of CNTs. Odegard et al. [1] presented a constitutive modelling of nanotube-reinforced polymer composites with nanotube/polymer interface modeled as an effective continuum fiber by using an equivalentcontinuum model. Gary et al. [2] obtained the effective elastic properties of CNTRCs through a

\footnotetext{
${ }^{1}$ PhD., Department of Mechanical Engineering, Kashan Branch, Islamic Azad University, Kashan, Iran, e-mail: r.kolahchi@gmail.com, mo.safari@gmail.com

${ }^{2}$ Eng., Young Researchers and Elite Club, Damavand Branch, Islamic Azad University, Damavand, Iran, e-mail: masoud.esma@gmail.com
} 
variety of micromechanic techniques. The effective properties of CNTs were calculated utilizing composite cylinder micromechanic techniques. Fidelus et al. [3] examined the thermo-mechanical properties of epoxy-based nanocomposites based on low weight fractions of randomly oriented single- and multi-walled carbon nanotubes. Han and Elliot [4] presented classical molecular dynamic (MD) simulations of model polymer/CNT composites constructed by embedding a SWCNT into two different amorphous polymer matrices. Using the MD method, the stress-strain behavior of SWCNTreinforced composites was studied by Zhu et al. [5].

Although these studies are quite useful, the ultimate purpose of the development of this advanced material is to explore the potential applications of CNTRCs in actual structures, such as CNTreinforced beams, plates or shells. Based on the Timoshenko beam theory, non-linear free vibrations of functionally graded CNTRC beams were analyzed with the Ritz method and direct iterative technique by Ke et al. [6]. For improving buckling and postbuckling behaviors of CNTRC structures, Shen and Zhang [7] investigated the thermal buckling and postbuckling behaviors of FG-CNTRC plates. Wang and Shen [8] used an improved perturbation technique to investigate nonlinear vibration of FG-SWCNT plates resting on an elastic foundation in thermal environments. Ghorbanpour Arani et al. [9] investigated the buckling behavior of laminated CNTRC plates, analytically based on the CLPT. Using the finite element method (FEM), analyses of bending and free vibration were carried out for various types of functionally graded CNTRC plates by Zhu et al. [10]. Yas and Heshmati [11] used the Timoshenko beam theory to analyze vibration of nanocomposite beams reinforced by randomly oriented straight SWCNTs subjected to a moving load. Recently, wave propagation analysis of a functionally graded carbon nanotube reinforced piezoelectric composite (FG-CNTRPC) is studied by Ghorbanpour Arani et al. [12].

In the present study, buckling analysis of temperature-dependent plates reinforced by FG-SWCNTs subjected to a magnetic field is studied based on orthotropic Mindlin plate theory. The rule of mixture is used in order to obtain the equivalent material properties of FG-CNTRC plate. Based on Hamilton's principal and energy method, the governing equations are obtained. The effects of the volume fractions of carbon nanotubes, elastic medium, magnetic field, temperature, and distribution type of CNTs on the buckling load of the FG-CNTRC polymeric plate are discussed in detail.

\section{FORMULATION}

As shown in Fig. 1, an embedded CNTRC plate with length $L$, width $b$ and thickness $h$ is considered. The CNTRC plate is surrounded by an orthotropic elastomeric temperature-dependent medium which 
is simulated by $K, G$ corresponding to the Winkler foundation parameter and, shear foundation parameters, respectively. Four types of CNTRC plates, namely uniform distribution (UD), along with three types of FG distributions (FGA, FGO, FGX) of CNTs along the thickness direction of a CNTRC plate is considered.

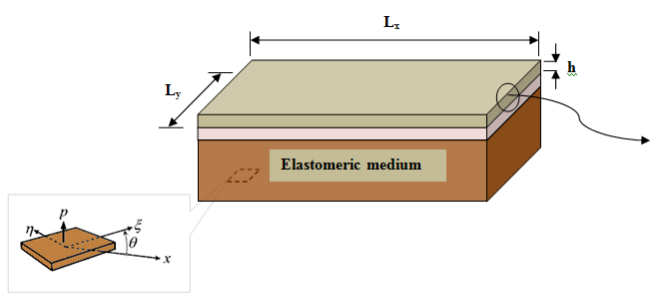

(a)

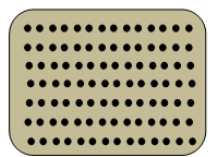

(c)

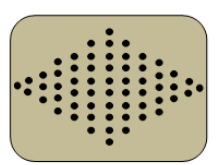

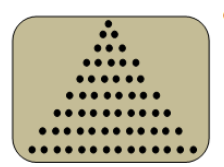

(b)

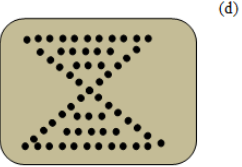

Fig. 1. Configurations of the nano-composite plates. (a) UD; (b) FG-A; (c) FG-O; (d) FG-X.

The constitutive equation for stresses $\boldsymbol{\sigma}$ and strains $\boldsymbol{\varepsilon}$ matrix in the thermal environment may be written as follows:

$$
\left\{\begin{array}{l}
\sigma_{x x} \\
\sigma_{y y} \\
\sigma_{y z} \\
\sigma_{z x} \\
\sigma_{x y}
\end{array}\right\}=\left[\begin{array}{ccccc}
C_{11}(z, T) & C_{12}(z, T) & 0 & 0 & 0 \\
C_{21}(z, T) & C_{22}(z, T) & 0 & 0 & 0 \\
0 & 0 & C_{44}(z, T) & 0 & 0 \\
0 & 0 & 0 & C_{55}(z, T) & 0 \\
0 & 0 & 0 & 0 & C_{66}(z, T)
\end{array}\right]\left\{\begin{array}{l}
\varepsilon_{x x}-\alpha_{x x} \Delta T \\
\varepsilon_{y y}-\alpha_{y y} \Delta T \\
\gamma_{y z} \\
\gamma_{x z} \\
\gamma_{x y}
\end{array}\right\},
$$

where $C_{i j}$ are elastic constants. The strain-displacement relations may be written as [13]:

$$
\begin{gathered}
\varepsilon_{x x}=\frac{\partial u_{0}}{\partial x}+\frac{1}{2}\left(\frac{\partial w_{0}}{\partial x}\right)^{2}+z \frac{\partial \varphi_{x}}{\partial x}, \varepsilon_{y y}=\frac{\partial v_{0}}{\partial y}+\frac{1}{2}\left(\frac{\partial w_{0}}{\partial y}\right)^{2}+z \frac{\partial \varphi_{y}}{\partial y} \\
\gamma_{y z}=\frac{\partial w_{0}}{\partial y}+\varphi_{y}, \gamma_{x z}=\frac{\partial w_{0}}{\partial x}+\varphi_{x}, \gamma_{x y}=\frac{\partial v_{0}}{\partial y}+\frac{\partial u_{0}}{\partial x}+\frac{\partial w_{0}}{\partial x} \frac{\partial w_{0}}{\partial y}+z\left(\frac{\partial \varphi_{x}}{\partial y}+\frac{\partial \varphi_{y}}{\partial x}\right)
\end{gathered}
$$

where $\left(u_{0}, v_{0}, w_{0}\right)$ are the mid-plane displacement along the $x$-, $y$-, and $z$-directions, respectively; $\varphi_{x}(x, y)$ and $\varphi_{y}(x, y)$ are the rotations about $x$ - and $y$-directions, respectively. 


\section{Mixture RULe}

In order to obtain the equivalent material properties of two-phase nanocomposites (i.e. polymer as matrix and CNT as reinforcer), the rule of mixture [14] is applied. According to the mixture rule, the effective Young and shear moduli of CNTRC plate can be written as

$$
E_{11}=\eta_{1} V_{C N T} E_{r 11}+\left(1-V_{C N T}\right) E_{m}, \frac{\eta_{2}}{E_{22}}=\frac{V_{C N T}}{E_{r 22}}+\frac{\left(1-V_{C N T}\right)}{E_{m}}, \frac{\eta_{3}}{G_{12}}=\frac{V_{C N T}}{G_{r 12}}+\frac{\left(1-V_{C N T}\right)}{G_{m}},
$$

where $E_{r 11}, E_{r 22}$ and $G_{r 11}$ indicate the Young's moduli and shear modulus of SWCNTs, respectively, and $E_{m}, G_{m}$ represent the corresponding properties of the isotropic matrix; $\eta_{j}(\mathrm{j}=1,2,3)$ are the scale-dependent material properties. $V_{C N T}$ and $V_{m}$ are the volume fractions of the CNTs and matrix, respectively, in which the sum equals to unity. The uniform and three types of FG distributions of the CNTs along the thickness direction take the following forms:

$$
\begin{gathered}
U D: V_{C N T}=V_{C N T}^{*}, F G V: V_{C N T}(z)=\left(1-\frac{2 z}{h}\right) V_{C N T}^{*}, \\
F G O: \quad V_{C N T}(z)=2\left(1-\frac{2|z|}{h}\right) V_{C N T}^{*}, F G X: V_{C N T}(z)=2\left(\frac{2|z|}{h}\right) V_{C N T}^{*},
\end{gathered}
$$

where

$$
V_{C N T}^{*}=\frac{w_{C N T}}{w_{C N T}+\left(\rho_{C N T} / \rho_{m}\right)-\left(\rho_{C N T} / \rho_{m}\right) w_{C N T}},
$$

where $w_{C N T}, \rho_{m}$ and $\rho_{C N T}$ are the mass fraction of the CNT, the densities of the matrix and CNT, respectively. Similarly, the thermal expansion coefficients in the longitudinal and transverse directions respectively $\left(\alpha_{11}\right.$ and $\left.\alpha_{22}\right)$, Poisson's ratio $\left(v_{12}\right)$ and the density ( $\rho$ ) of the CNTRC plates can be determined as 


$$
\begin{gathered}
v_{12}=V_{C N T}^{*} v_{r 12}+V_{m}, v_{m}, \rho=V_{C N T}^{*} \rho_{r}+V_{m}, \rho_{m}, \alpha_{11}=V_{C N T}^{*} \alpha_{r 11}+V_{m} \alpha_{m,}, \\
\alpha_{22}=\left(1+v_{r 12}\right) V_{C N T} \alpha_{r 22}+\left(1+v_{m}\right) V_{m} \alpha_{m}-v_{12} \alpha_{11},
\end{gathered}
$$

where $v_{r 12}$ and $v_{m}$ are Poisson's ratios of the CNT and matrix, respectively. In addition, $\alpha_{r 11}, \alpha_{r 22}$ and $\alpha_{m}$ are the thermal expansion coefficients of the CNT and matrix, respectively. It should be noted that $v_{12}$ is assumed as constant over the thickness of the FG-CNTRC plates.

\section{GOVERNING EQUATIONS}

The total potential energy, $V$, of the CNTRC plate is the sum of strain energy, $U$ and the work done by the external force, $W$.

\subsection{POTENTIAL ENERGY}

The potential energy can be written as

$$
U=\frac{1}{2} \int_{\Omega_{0}} \int_{-h / 2}^{h / 2}\left(\sigma_{x x} \varepsilon_{x x}+\sigma_{y y} \varepsilon_{y y}+\sigma_{x y} \gamma_{x y}+\sigma_{x z} \gamma_{x z}+\sigma_{y z} \gamma_{y z}\right) d V
$$

Combining of Eqs. (2.1), (2.2) and (4.1) yields

$$
\begin{aligned}
& U=\frac{1}{2} \int_{\Omega_{0}}\left(N_{x x}\left(\frac{\partial u_{0}}{\partial x}+\frac{1}{2}\left(\frac{\partial w_{0}}{\partial x}\right)^{2}\right)+N_{y y}\left(\frac{\partial v_{0}}{\partial y}+\frac{1}{2}\left(\frac{\partial w_{0}}{\partial y}\right)^{2}\right)+N_{y z}\left(\frac{\partial w_{0}}{\partial y}+\varphi_{y}\right)+N_{x z}\left(\frac{\partial w_{0}}{\partial x}+\varphi_{x}\right)\right. \\
& \left.+N_{x y}\left(\frac{\partial v_{0}}{\partial y}+\frac{\partial u_{0}}{\partial x}+\frac{\partial w_{0}}{\partial x} \frac{\partial w_{0}}{\partial y}\right)+M_{x x} \frac{\partial \varphi_{x}}{\partial x}+M_{y y} \frac{\partial \varphi_{y}}{\partial x}+M_{x y}\left(\frac{\partial \varphi_{x}}{\partial y}+\frac{\partial \varphi_{y}}{\partial x}\right)\right) d x d y
\end{aligned}
$$

where the stress resultant-displacement relations can be written as

$$
\left[\begin{array}{ll}
N_{x x} & M_{x x} \\
N_{y y} & M_{y y} \\
N_{x y} & M_{x y}
\end{array}\right]=\int_{-h / 2}^{h / 2}\left[\begin{array}{c}
\sigma_{x x} \\
\sigma_{y y} \\
\sigma_{x y}
\end{array}\right](1, z) d z,\left[\begin{array}{l}
N_{x z} \\
N_{y z}
\end{array}\right]=K \int_{-h / 2}^{h / 2}\left[\begin{array}{l}
\sigma_{x z} \\
\sigma_{y z}
\end{array}\right] d z,
$$

In which $K$ is shear correction coefficient. 


\subsection{EXTERNAL WORK}

\subsubsection{ElastiC MEDIUM}

The external work due to orthotropic temperature-dependent elastomeric medium and a uniform load on the upper surface of the CNTRC plate can be written as [15]

$$
W=-\int_{0}^{L}\left(K W-G \nabla^{2} W\right) w d x
$$

where $K$ and $G$ are spring and shear constants. Since the elastomeric medium is relatively soft, the foundation stiffness $K$ may be expressed by

$$
K=\frac{E_{0}}{4 L\left(1-v_{0}^{2}\right)\left(2-c_{1}\right)^{2}}\left[5-\left(2 \gamma_{1}^{2}+6 \gamma_{1}+5\right) \exp \left(-2 \gamma_{1}\right)\right]
$$

where

$$
c_{1}=\left(\gamma_{1}+2\right) \exp \left(-\gamma_{1}\right), \gamma_{1}=\frac{H_{s}}{L}, E_{0}=\frac{E_{s}}{\left(1-v_{s}^{2}\right)}, v_{0}=\frac{v_{s}}{\left(1-v_{s}\right)} \text {, }
$$

where $E_{s}, v_{s}, H_{s}$ are Young's modulus, Poisson's ratio and depth of the foundation, respectively. In this paper, $E_{s}$ is assumed to be temperature-dependent while $v_{s}$ is assumed to be a constant.

\subsubsection{MAGNETIC FIELD}

For a plate subjected to a steady magnetic field, $\mathbf{H}_{0}$, the exerted body force may be calculated as follows [14]

$$
\mathbf{f}_{m}=\eta \times\left(\nabla \times\left(\nabla \times\left(\mathbf{u} \times \mathbf{H}_{0}\right)\right)\right) \times \mathbf{H}_{0},
$$


where $\eta$ is the magnetic permeability; $\nabla$ is the gradient operator and $\mathbf{u}$ is the displacement field vector. Considering $\mathbf{H}_{0}=H_{x} \hat{i}$, the components of the Lorentz force per unit volume of the plate are evaluated by

$$
f_{m z}=\eta H_{x}^{2}\left(\frac{\partial^{2} w}{\partial x^{2}}\right)
$$

\subsection{HAMILTON'S PRINCIPAL}

The governing equations can be derived by Hamilton's principal as follows

$$
\left\{\begin{array}{l}
\delta u_{0}=0 \rightarrow\left(N_{x x, x}+N_{\mathrm{xy}, \mathrm{y}}\right)=0 \\
\delta v_{0}=0 \rightarrow\left(N_{\mathrm{yy}, \mathrm{y}}+N_{\mathrm{xy}, \mathrm{x}}\right)=0 \\
\delta w_{0}=0 \rightarrow\left(\left(N_{x x} \frac{\partial w_{0}}{\partial x}\right)_{, x}+\left(N_{y y} \frac{\partial w_{0}}{\partial y}\right)_{, \mathrm{y}}+\left(N_{x y} \frac{\partial w_{0}}{\partial y}\right)_{, x}\right. \\
+\left(N_{x y} \frac{\partial w_{0}}{\partial x}\right)_{, y}+N_{x z, x}+N_{y z, y}-K W+G \nabla^{2} W+\eta h H_{x}^{2}\left(\frac{\partial^{2} w}{\partial x^{2}}+\frac{\partial \psi_{y}}{\partial y}\right)=0 \\
\delta \varphi_{x}=0 \rightarrow\left(M_{\mathrm{xx}, \mathrm{x}}+M_{\mathrm{xy}, \mathrm{y}}-N_{x z}\right)=0 \\
\delta \varphi_{y}=0 \rightarrow\left(M_{\mathrm{yy}, \mathrm{y}}+M_{\mathrm{xy}, \mathrm{x}}-N_{y z}\right)=0
\end{array}\right.
$$

Substituting Eqs. (2.1) and (2.2) into Eq. (4.3), the stress resultant-displacement relations can be obtained as follows

$$
\begin{gathered}
N_{x x}=\int_{-h}^{h} \sigma_{x x} d z=A_{11}\left(\frac{\partial u_{0}}{\partial x}\right)+B_{11} \frac{\partial \varphi_{x}}{\partial x}+A_{12}\left(\frac{\partial v_{0}}{\partial x}\right)+B_{12} \frac{\partial \varphi_{y}}{\partial y} \\
N_{y y}=\int_{-h}^{h} \sigma_{y y} d z=A_{12}\left(\frac{\partial u_{0}}{\partial x}\right)+B_{12} \frac{\partial \varphi_{x}}{\partial x}+A_{22}\left(\frac{\partial v_{0}}{\partial x}\right)+B_{22} \frac{\partial \varphi_{y}}{\partial y} \\
N_{x y}=\int_{-h}^{h} \sigma_{x y} d z=A_{33}\left(\frac{\partial u_{0}}{\partial y}+\frac{\partial v_{0}}{\partial x}\right)+B_{33}\left(\frac{\partial \varphi_{x}}{\partial y}+\frac{\partial \varphi_{y}}{\partial x}\right) \\
M_{x x}=\int_{-h}^{h} \sigma_{x x} z d z \int=B_{11}\left(\frac{\partial u_{0}}{\partial x}\right)+D_{11} \frac{\partial \varphi_{x}}{\partial x}+B_{12}\left(\frac{\partial v_{0}}{\partial x}\right)+D_{12} \frac{\partial \varphi_{y}}{\partial y}
\end{gathered}
$$




$$
\begin{gathered}
M_{y y}=\int_{-h}^{h} \sigma_{y y} z d z=B_{12}\left(\frac{\partial u_{0}}{\partial x}\right)+D_{12} \frac{\partial \varphi_{x}}{\partial x}+B_{22}\left(\frac{\partial v_{0}}{\partial x}\right)+D_{22} \frac{\partial \varphi_{y}}{\partial y}, \\
M_{x y}=\int_{-h}^{h} \sigma_{x y} z d z=B_{33}\left(\frac{\partial u_{0}}{\partial y}+\frac{\partial v_{0}}{\partial x}\right)+D_{33}\left(\frac{\partial \varphi_{x}}{\partial y}+\frac{\partial \varphi_{y}}{\partial x}\right), \\
M_{y z}=\int_{-h}^{h} \sigma_{y z} z d z=B_{44}\left(\varphi_{y}+\frac{\partial w_{0}}{\partial y}\right), \\
M_{x z}=\int_{-h}^{h} \sigma_{x z} z d z=B_{55}\left(\varphi_{x}+\frac{\partial w_{0}}{\partial x}\right),
\end{gathered}
$$

where

$$
A_{i j}=\int_{-h / 2}^{h / 2} C_{i j} d z, B_{i j}=\int_{-h / 2}^{h / 2} C_{i j} z d z, D_{i j}=\int_{-h / 2}^{h / 2} C_{i j} z^{2} d z
$$

Substituting Eqs. (4.10) to (4.18) into Eq. (4.9), the governing equations can be written as follows

$$
\begin{gathered}
\frac{\partial}{\partial x}\left[A_{11}\left(\frac{\partial u_{0}}{\partial x}\right)+B_{11} \frac{\partial \varphi_{x}}{\partial x}+A_{12}\left(\frac{\partial v_{0}}{\partial x}\right)+B_{12} \frac{\partial \varphi_{y}}{\partial y}\right]+\frac{\partial}{\partial y}\left[A_{33}\left(\frac{\partial u_{0}}{\partial y}+\frac{\partial v_{0}}{\partial x}\right)+B_{33}\left(\frac{\partial \varphi_{x}}{\partial y}+\frac{\partial \varphi_{y}}{\partial x}\right)\right]=0 \\
\frac{\partial}{\partial y}\left[A_{12}\left(\frac{\partial u_{0}}{\partial x}\right)+B_{12} \frac{\partial \varphi_{x}}{\partial x}+A_{22}\left(\frac{\partial v_{0}}{\partial x}\right)+B_{22} \frac{\partial \varphi_{y}}{\partial y}\right]+\frac{\partial}{\partial x}\left[A_{33}\left(\frac{\partial u_{0}}{\partial y}+\frac{\partial v_{0}}{\partial x}\right)+B_{33}\left(\frac{\partial \varphi_{x}}{\partial y}+\frac{\partial \varphi_{y}}{\partial x}\right)\right]=0 \\
\frac{\partial}{\partial x}\left(\left(A_{11}\left(\frac{\partial u_{0}^{2}}{\partial x}\right)+B_{11} \frac{\partial \varphi_{x}}{\partial x}+A_{12}\left(\frac{\partial v_{0}}{\partial x}\right)+B_{12} \frac{\partial \varphi_{y}}{\partial y}\right) \frac{\partial w_{0}}{\partial x}\right)+\frac{\partial}{\partial y}\left(\left(A_{12}\left(\frac{\partial u_{0}}{\partial x}\right)+B_{12} \frac{\partial \varphi_{x}}{\partial x}+A_{22}\left(\frac{\partial v_{0}}{\partial x}\right)+B_{22} \frac{\partial \varphi_{y}}{\partial y}\right) \frac{\partial w_{0}}{\partial y}\right)+ \\
\frac{\partial}{\partial x}\left(\left(A_{33}\left(\frac{\partial u_{0}}{\partial y}+\frac{\partial v_{0}}{\partial x}\right)+B_{33}\left(\frac{\partial \varphi_{x}}{\partial y}+\frac{\partial \varphi_{y}}{\partial x}\right)\right) \frac{\partial w_{0}}{\partial y}\right)+\frac{\partial}{\partial y}\left(\left(A_{33}\left(\frac{\partial u_{0}}{\partial y}+\frac{\partial v_{0}}{\partial x}\right)+B_{33}\left(\frac{\partial \varphi_{x}}{\partial y}+\frac{\partial \varphi_{y}}{\partial x}\right)\right) \frac{\partial w_{0}}{\partial x}\right)+ \\
\frac{\partial}{\partial y}\left(A_{44}\left(\varphi_{y}+\frac{\partial w_{0}}{\partial y}\right)\right)+\frac{\partial}{\partial x}\left(A_{55}\left(\varphi_{x}+\frac{\partial w_{0}}{\partial x}\right)\right)+\left(-K W+G \nabla^{2} W\right)+\eta h H_{x}^{2}\left(\frac{\partial^{2} w}{\partial x^{2}}+\frac{\partial \psi_{y}}{\partial y}\right)=0 \\
\frac{\partial}{\partial x}\left(B_{11}\left(\frac{\partial u_{0}}{\partial x}\right)+D_{11} \frac{\partial \varphi_{x}}{\partial x}+B_{12}\left(\frac{\partial v_{0}}{\partial x}\right)+D_{12} \frac{\partial \varphi_{y}}{\partial y}\right)+\frac{\partial}{\partial y}\left(B_{33}\left(\frac{\partial u_{0}}{\partial y}+\frac{\partial v_{0}}{\partial x}\right)+D_{33}\left(\frac{\partial \varphi_{x}}{\partial y}+\frac{\partial \varphi_{y}}{\partial x}\right)\right)-\left(A_{55}\left(\varphi_{x}+\frac{\partial w_{0}}{\partial x}\right)\right)=0 \\
\quad \frac{\partial}{\partial y}\left(B_{12}\left(\frac{\partial u_{0}}{\partial x}\right)+D_{12} \frac{\partial \varphi_{x}}{\partial x}+B_{22}\left(\frac{\partial v_{0}}{\partial x}\right)+D_{22} \frac{\partial \varphi_{y}}{\partial y}\right)+\frac{\partial}{\partial x}\left(B_{33}\left(\frac{\partial u_{0}}{\partial y}+\frac{\partial v_{0}}{\partial x}\right)+D_{33}\left(\frac{\partial \varphi_{x}}{\partial y}+\frac{\partial \varphi_{y}}{\partial x}\right)\right)-\left(A_{44}\left(\varphi_{y}+\frac{\partial w_{0}}{\partial y}\right)\right)=0
\end{gathered}
$$




\section{EXACT SOLUTION}

Steady state solutions to the governing equations of the plate which relate to the simply supported boundary conditions can be assumed as [13]

$$
\begin{aligned}
u(x, \theta, t)=\sum_{m=1}^{\infty} \sum_{n=1}^{\infty} u_{m n} \cos \left(\frac{m \pi x}{L_{x}}\right) \sin \left(\frac{n \pi y}{L_{y}}\right), v(x, \theta, t)=\sum_{m=1}^{\infty} \sum_{n=1}^{\infty} v_{m n} \sin \left(\frac{m \pi x}{L_{x}}\right) \cos \left(\frac{n \pi y}{L_{y}}\right), \\
w(x, \theta, t)=\sum_{m=1}^{\infty} \sum_{n=1}^{\infty} w_{m n} \sin \left(\frac{m \pi x}{L_{x}}\right) \sin \left(\frac{n \pi y}{L_{y}}\right) \\
\phi_{x}(x, \theta, t)=\sum_{m=1}^{\infty} \sum_{n=1}^{\infty} \psi_{x m n} \cos \left(\frac{m \pi x}{L_{x}}\right) \cos \left(\frac{n \pi y}{L_{y}}\right) \\
\phi_{y}(x, \theta, t)=\sum_{m=1}^{\infty} \sum_{n=1}^{\infty} \psi_{y_{m n}} \sin \left(\frac{m \pi x}{L_{x}}\right) \cos \left(\frac{n \pi y}{L_{y}}\right)
\end{aligned}
$$

Substituting the above ratios into the governing equations turns it into an algebraic equation expressed as

$$
\left[\begin{array}{lllll}
K_{11} & K_{12} & K_{13} & K_{14} & K_{15} \\
K_{21} & K_{22} & K_{23} & K_{24} & K_{25} \\
K_{31} & K_{32} & K_{33} & K_{34} & K_{35} \\
K_{41} & K_{42} & K_{43} & K_{44} & K_{45} \\
K_{51} & K_{52} & K_{53} & K_{54} & K_{55}
\end{array}\right]\left[\begin{array}{l}
u_{m n} \\
v_{m n} \\
w_{m n} \\
\psi_{x m n} \\
\psi_{y m n}
\end{array}\right]=0,
$$

where $K_{i j}$ are constant. Setting the determinate of the above equation equal to zero yields the buckling load of system.

\section{NUMERICAL RESULTS AND DISCUSSION}

A computer program is prepared for the numerical solution of buckling of CNTRC plates resting on an elastic temperature-dependent foundation. Here, Poly methyl methacrylate (PMMA) is selected for the matrix which has constant Poisson's ratios of $v_{m}=0.34$, a temperature-dependent thermal coefficient of $\alpha_{m}=(1+0.0005 \Delta T) \times 10^{-6} / K$, and temperature-dependent Young moduli of 
$E_{m}=(3.52-0.0034 T) G P a$ in which $T=T_{0}+\Delta T$ and $T_{0}=300 \mathrm{~K}$ (room temperature). In addition, $(10,10)$ SWCNTs are selected as reinforcements with the material properties listed in Table 1.

Table 1. Temperature-dependent material properties of $(10,10) \operatorname{SWCNT}(\mathrm{L}=9.26 \mathrm{~nm}, \mathrm{R}=0.68 \mathrm{~nm}$,

$$
\left.\mathrm{h}=0.067 \mathrm{~nm}, v_{12}^{C N T}=0.175\right)
$$

\begin{tabular}{llllll}
\hline Temperature $(\mathrm{K})$ & $E_{11}^{C N T}(\mathrm{TPa})$ & $E_{22}^{C N T}(\mathrm{TPa})$ & $G_{12}^{C N T}(\mathrm{TPa})$ & $\alpha_{12}^{C N T}\left(10^{-6} / K\right)$ & $\alpha_{22}^{C N T}\left(10^{-6} / \mathrm{K}\right)$ \\
\hline 300 & 5.6466 & 7.0800 & 1.9445 & 3.4584 & 5.1682 \\
500 & 5.5308 & 6.9348 & 1.9643 & 4.5361 & 5.0189 \\
700 & 5.4744 & 6.8641 & 1.9644 & 4.6677 & 4.8943 \\
\hline
\end{tabular}

The elastomeric medium is made of Poly dimethylsiloxane (PDMS) where the temperaturedependent material properties of which are assumed to be $v_{s}=0.48$ and $E_{s}=(3.22-0.0034 T) G P a$ in which $T=T_{0}+\Delta T$ and $T_{0}=300 \mathrm{~K}$ (room temperature) [16].

Depicted in Fig. 2 is the buckling load for the UD and three types of FG CNTRC plates versus length. It should be noted that the mass fraction $\left(w_{C N T}\right)$ of the UD and FG distribution of CNTs in polymer are considered equal for the purpose of comparisons. As can be seen, the buckling load of FGA- and FGO- CNTRC plates are lower than the buckling load of UD-CNTRC plates while the FGX-CNTRC plate has higher buckling load with respect to the three other cases. It is due to the fact that the stiffness of CNTRC plates changes with the form of CNT distribution in the matrix. However, it can be concluded that CNT distribution close to the top and bottom are more efficient than those distributed near the mid-plane for increasing the stiffness of plates. In addition, increasing length can decrease the buckling load of the CNTRC plate. This is because with increasing length, the stability of the plate decreases.

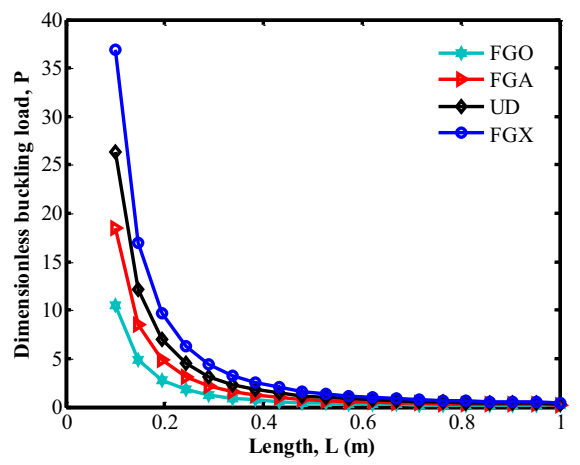

Fig. 2. Effects of CNT distribution on the buckling behavior of CNTRC plates versus length

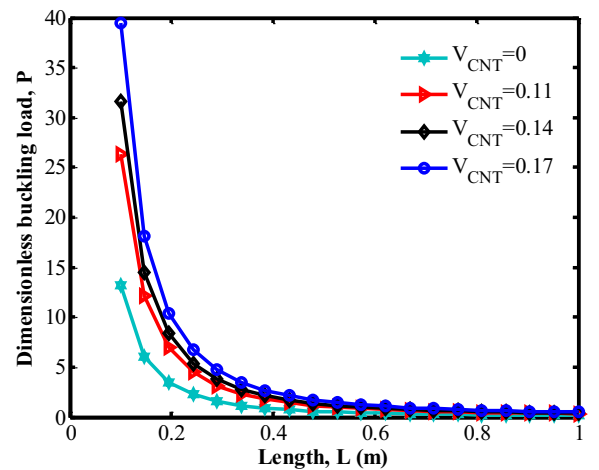

Fig. 3. Effects of CNT volume fraction on the buckling behavior of CNTRC plates versus length 
The effect of the CNT volume fraction on the buckling load of the CNTRC plate with respect to length is shown in Fig. 3. It can be found that thickening the plate can decrease the buckling load of the CNTRC plate. It is also observed that increasing the CNT volume fraction increases the buckling load of the CNTRC plate. This is due to the fact that the increase of CNT volume fraction leads to a harder structure. Meanwhile, the effect of CNT volume fraction becomes more considerable at a shorter length.

The effect of the elastic temperature-dependent medium on the buckling load of the CNTRC plate with respect to length is illustrated in Fig. 4. In this figure three cases are considered without elastic medium; Winkler medium and Pasternak medium. As can be seen, considering elastic medium increases the buckling load of the CNTRC plate. This is due to the fact that considering elastic medium leads to stiffer structure. Furthermore, the effect of the Pasternaktype is higher than the Winklertype on the buckling load of the CNTRC plate. It is perhaps due to the fact that the Winklertype is only capable of describing a normal load of the elastic medium while the Pasternaktype describes both transverse shear and normal loads of the elastomeric medium.

The effect of temperature on the buckling load of the CNTRC plate with respect to the length is demonstrated in Fig. 5. As in the other figures, increasing the length decreases the buckling load of the CNTRC plate. It can be also found that the buckling load of the CNTRC plate decreases with increasing temperature which is due to the higher stiffness of CNTRC plate with lower temperature.

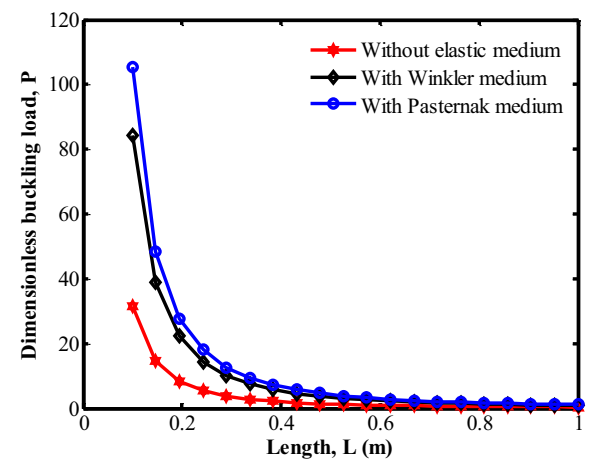

Fig. 4. Effects of elastic medium on the buckling behavior of CNTRC plates versus length

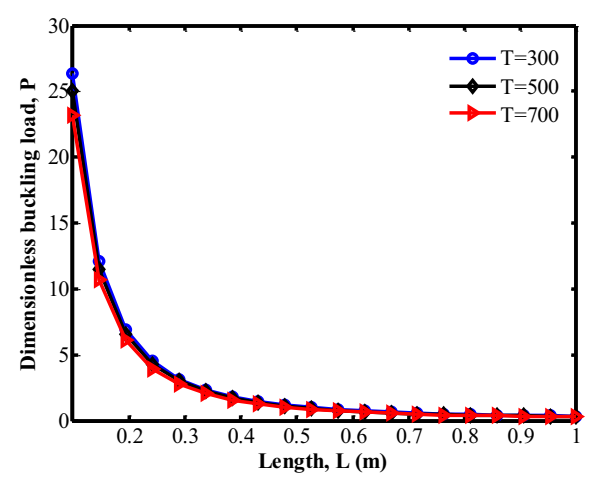

Fig. 5. Effects of temperature on the buckling behavior of CNTRC plates versus length

Fig. 6 illustrates the effect of magnetic field on the buckling load of the plate with respect to the length. As in the other figures, increasing the length decreases the buckling load of the CNTRC plate. 
It can be also found that the buckling load of the CNTRC plate increases with increasing magnetic field which is due to the higher stiffness CNTRC plate with a higher magnetic field.

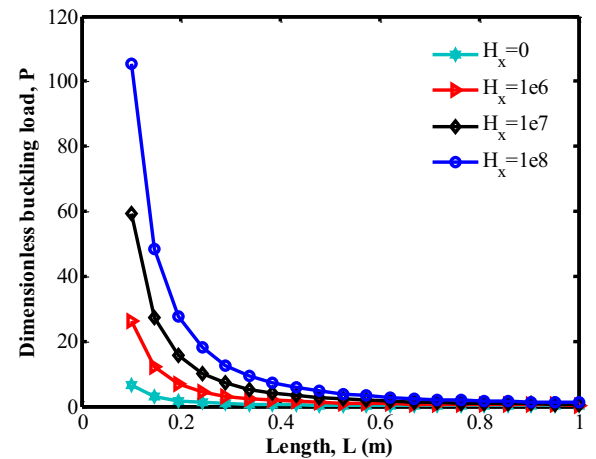

Fig. 6. Effects of magnetic field on the buckling behavior of CNTRC plates versus length

\section{CONCLUSION}

Magneto-thermo-mechanical buckling analysis of an embedded plate was studied in this paper based on orthotropic Mindlin plate theory. SWCNT distributions in polymer were considered as UD, FGA, FGX and FGO and the equivalent material properties of structure are obtained using rule of mixture. The elastic medium is simulated by a temperature-dependent Pasternak foundation. Using straindisplacement relation, energy method and Hamilton's principle, the governing equations were derived. In order to obtain the buckling load of the FG-SWCNT-reinforced plate, the Navier method was performed. The effects of the volume fractions of carbon nanotubes, magnetic field, elastic medium, temperature, length and distribution type of CNTs were considered. Results indicate that considering elastic medium increases the buckling load of the FG-CNTRC plate. It was also concluded that the buckling load gets larger as the CNT volume fraction increases. Furthermore, the lowest and highest buckling loads were obtained for FGO- and FGX-CNTRC plates, respectively. In addition, increasing magnetic field increases the buckling load of structure. 


\section{REFERENCES}

1. G.M. Odegard, T.S. Gates, K.E. Wise, C. Park, E.J. Siochi, "Constitutive modeling of nanotube-reinforced polymer composites", Composite Science and Technology 63:1671-87, 2003.

2. G.D. Seidel, D.C. Lagoudas, "Micromechanical analysis of the effective elastic properties of carbon nanotube reinforced composites", Mechnics of Materials 38:884-907, 2006.

3. J.D. Fidelus, E. Wiesel, F.H. Gojny, K. Schulte, H.D. Wagner, "Thermo-mechanical properties of randomly oriented carbon/epoxy nanocomposites", Composites: Part A 36:1555-61, 2005.

4. Y. Han, J. Elliott, "Molecular dynamics simulations of the elastic properties of polymer/carbon nanotube composites", Computational Material Science 39:315-23, 2007.

5. R. Zhu, E. Pan, A.K. Roy, "Molecular dynamics study of the stress-strain behaviour of carbon-nanotube reinforced Epon 862 composites”, Material Science Engineering A 447:51-7, 2007.

6. L.L. Ke, J. Yang, S. Kitipornchai, "Nonlinear free vibration of functionally graded carbon nanotube-reinforced composite beams", Composite Structures 92:676-83, 2010.

7. Shen HS, Zhang CL. "Thermal buckling and postbuckling behavior of functionally graded carbon nanotubereinforced composite plates", Mater Des 2010;31:3403-11.

8. Z.X. Wang, H.S. Shen, "Nonlinear vibration of nanotube-reinforced composite plates in thermal environments", Composite Structures 50:2319-2330, 2011.

9. A. Ghorbanpour Arani, S. Maghamikia, M. Mohammadimehr, A. Arefmanesh, "Buckling analysis of laminated composite rectangular plates reinforced by SWCNTs using analytical and finite element methods", Journal of Mechanical Science and Technology 25: 809-820, 2011.

10. P. Zhu, Z.X. Lei, K.M. Liew, "Static and free vibration analyses of carbon nanotubereinforced composite plates using finite element method with first order shear deformation plate theory", Composite Structures 94:1450-60, 2012.

11. M.H. Yas, M. Heshmati, "Dynamic analysis of functionally graded nanocomposite beams reinforced by randomly oriented carbon nanotube under the action of moving load", Applied Mathematical Modeling 36:13711394, 2012.

12. A. Ghorbanpour Arani, M. Jamali, M. Mosayyebi, R. Kolahchi, "Analytical modeling of wave propagation in viscoelastic functionally graded carbon nanotubes reinforced piezoelectric microplate under electro-magnetic field", Proc IMechE Part N: J Nanoengineering and Nanosystems, In press.

13. A. Ghorbanpour Arani, R. Kolahchi, H. Vossough, "Buckling analysis and smart control of SLGS using elastically coupled PVDF nanoplate based on the nonlocal Mindlin plate theory", Physica B 407:44584465,2012 .

14. R. Kolahchi, M. Rabani Bidgoli, Gh. Beygipoor, M.H. Fakhar, "A nonlocal nonlinear analysis for buckling in embedded FG-SWCNT-reinforced microplates subjected to magnetic field”, Journal of Mechanical Science and Technology 29:3669 3677, 2015.

15. R. Kolahchi, A.M. Moniribidgoli, "Size-dependent sinusoidal beam model for dynamic instability of singlewalled carbon nanotubes, Appllied Mathematics and Mechanics 37, 265-274, 2016.

16. Sh. Hui-Shen, "Nonlinear bending of functionally graded carbon nanotube-reinforced composite plates in thermal environments", Composite Structures 91:9-19, 2009. 


\section{LIST OF FIGURES AND TABLES:}

Fig. 1. Configurations of the nano-composite plates. (a) UD CNTRC plate; (b) FG-A CNTRC plate; (c) FGO CNTRC plate; (d) FG-X CNTRC plate.

Rys. 1. Konfiguracje płytek nanokompozytowych. (a) płytka UD CNTRC; (b) płytka FG-A CNTRC; (c) płytka FG-O CNTRC; (d) płytka FG-X CNTRC.

Fig. 2. Effects of CNT distribution on the buckling behavior of CNTRC plates versus length

Rys. 2. Wpływ rozkładu nanorurek na krytyczne zachowanie płytek CNTRC kontra długość płytki

Fig. 3. Effects of CNT volume fraction on the buckling behavior of CNTRC plates versus length

Rys. 3. Wpływ udziału objętościowego nanorurek na krytyczne zachowanie płytek CNTRC kontra długość płytki

Fig. 4. Effects of elastic medium on the buckling behavior of CNTRC plates versus length

Rys. 4. Wpływ ośrodka sprężystego na krytyczne zachowanie płytek CNTRC kontra długość płytki

Fig. 5. Effects of temperature on the buckling behavior of CNTRC plates versus length

Rys. 5. Wpływ temperatury na krytyczne zachowanie płytek CNTRC kontra długość płytki

Fig. 6. Effects of magnetic field on the buckling behavior of CNTRC plates versus length

Rys. 6. Wpływ pola magnetycznego na krytyczne zachowanie płytek CNTRC kontra długość płytki

Tab. 1. Temperature-dependent material properties of $(10,10) \operatorname{SWCNT}(\mathrm{L}=9.26 \mathrm{~nm}, \mathrm{R}=0.68 \mathrm{~nm}, \mathrm{~h}=$ $=0.067 \mathrm{~nm}, v_{12}^{C N T}=0.175$ )

Tab. 1. Właściwości materiału zależne od temperatury $(10,10)$ nanorurek $\operatorname{SWCNT}(\mathrm{L}=9,26 \mathrm{~nm}, \mathrm{R}=$ $=0,68 \mathrm{~nm}, \mathrm{~h}=0,067 \mathrm{~nm}, v_{12}^{C N T}=0,175$ ) 


\section{ANALIZA MAGNETYCZNO-TERMO-MECHANICZNA WYBOCZENIA PLYTY MINDLINA WZMACNIANEJ NANORURKAMI O FUNKCYJNEJ GRADACJI.}

Słowa kluczowe: Wyboczenie; Pole magnetyczne; nanorurki FG-SWCNT; zależne od temperatury; płyta Mindlina

\section{STRESZCZENIE:}

Badana jest analiza wyboczenia wbudowanych płyt zależnych od temperatury wzmacnianych jednościennymi nanorurkami węglowymi (SWCNT) poddawanych polu magnetycznemu. Nanorurki SWCNT są rozpowszechniane jako jednolite (UD), a także istnieją trzy typy rozmieszczenia FG (FGA, FGO, FGX). W celu uzyskania równoważnych właściwości materiałowych nanokompozytów dwufazowych (tj. polimer jako matryca i nanorurka węglowa jako wzmocnienie), stosuje się zasadę mieszaniny.

Do modelowania matematycznego obecnej struktury stosuje ortotropową teorię płyty Mindlina. W tej teorii odkształcenie normalne i przy ścinaniu są rozpatrywane w kategoriach przemieszczenia punktu materiału na płaszczyźnie środkowej i obrotów normalnej i środkowej płaszczyzny w kierunku osi X i Y. W celu uzyskania obowiązujących równań, stosowana jest metoda energetyczna i zasada Hamiltona. Całkowita energia potencjalna płytki CNTRC to suma energii odkształcenia i pracy wykonanej przez ośrodek elastomerowy i pole magnetyczne. W przypadku energii odkształcenia, zależności przemieszczania w wyniku naprężenia są definiowane w celu uproszczenia. Ośrodek sprężysty zależny od temperatury otoczenia jest stymulowany jako podłoże Pasternaka ze stałą sprężyny i ścinania. Ponieważ ośrodek elastomerowy jest stosunkowo miękki, zakłada się, że sztywność fundamentu jest zależna od temperatury. Ponadto, w przypadku płytki poddawanej stałemu polu magnetycznemu, bierze się pod uwagę przyłożoną siłę masową oraz ocenia się elementy siły Lorentza na jednostkę płytki. Na koniec, korzystając z zasady Hamiltona i integrując wg części, uzyskuje się obowiązujące równania w zakresie wypadkowych naprężeń. Następnie, obliczając wypadkową naprężenia pod względem przemieszczenia i obrotów, uzyskuje się ostateczną formę obowiązujących równań.

Obciążenie wyboczeniowe struktury jest obliczane na podstawie dokładnego rozwiązania metodą Naviera. W tej metodzie, zakłada się rozwiązania dla stanu ustalonego obowiązujących równań płytki, które po prostu odnoszą się do warunków brzegowych. Podstawiając równania Naviera do obowiązujących równań, stają się one równaniem algebraicznym. Ustawienie wyznaczenia wspomnianego równania na zero skutkuje obciążeniem wyboczeniowym układu. W tym celu program komputerowy jest przygotowany na rozwiązanie numeryczne wyboczenia płytki CNTRC na sprężystym fundamencie zależnym od temperatury.

Wpływy ośrodka sprężystego, pola magnetycznego, temperatury i typu rozmieszczenia nanorurek SWCNT i objętości frakcji nanorurek SWCNT są przedstawiane przez wyboczenie płytki. Tutaj do macierzy dobiera się polimetakrylan metylu (PMMA), a nanorurki SWCNT są wybierane jako wzmocnienia o właściwościach materiałowych zależnych od temperatury. Ponadto ośrodek elastomerowy jest wykonany z polidimetylosiloksanu (PDMS) o właściwościach materiałowych zależnych od temperatury. Wyniki wskazują, że obciążenia wyboczeniowe płytek FGA - i FGO-CNTRC są niższe niż obciążenia wyboczeniowe płytek UD-CNTRC, podczas gdy płytka FGX-CNTRC ma wyższe obciążenie wyboczeniowe w odniesieniu do trzech innych przypadków. Jest to spowodowane faktem, że sztywność płytek CNTRC zmienia się wraz z formą rozmieszczenia nanorurek węglowych w macierzy. Można jednak stwierdzić, że rozmieszczenie 
nanorurek węglowych blisko części górnej i dolnej jest wydajniejsze niż w przypadku nanorurek umieszczonych blisko płaszczyzny środkowej w celu zwiększenia sztywności płytki. Ponadto zwiększenie długości może zmniejszyć obciążenie wyboczeniowe płytki CNTRC. Jest to spowodowane faktem, iż wraz ze wzrostem długości, stabilność płytki spada. Można stwierdzić, że pogrubienie płytki może zmniejszyć obciążenie wyboczeniowe płytki CNTRC. Zauważono również, że zwiększenie frakcji objętości nanorurek węglowych zwiększa obciążenie wyboczeniowe płytki CNTRC. Jest to spowodowane faktem, iż zwiększenie frakcji objętości CNT prowadzi do utwardzenia struktury. Tymczasem wpływ objętości frakcji nanorurek węglowych staje się znaczny przy mniejszej długości. Jak widać, wzięcie pod uwagę ośrodka sprężystego zwiększa obciążenie wyboczeniowe płytki CNTRC. Jest to spowodowane faktem, że wzięcie pod uwagę ośrodka sprężystego prowadzi do usztywnienia struktury. Ponadto wpływ podłoża Pasternaka na obciążenie wyboczeniowe płytki CNTRC jest wyższy niż w przypadku podłoża Winklera. Być może jest to spowodowane faktem, że podłoże Winklera jest w stanie jedynie opisać normalne obciążenie ośrodka sprężystego, podczas gdy podłoże Pasternaka opisuje zarówno ścinanie poprzeczne i normalne obciążenia ośrodka elastomerowego. Można również stwierdzić, że obciążenie wyboczeniowe płytki CNTRC spada wraz ze wzrostem temperatury, co jest spowodowane większą sztywnością płytki CNTRC przy niższej temperaturze. Można również stwierdzić, że obciążenie wyboczeniowe płytki CNTRC wzrasta wraz ze wzrostem pola magnetycznego, co jest spowodowane większą sztywnością płytki CNTRC przy większym polu magnetycznym. 